\title{
Evaluasi Kualitas Layanan Website Alumni Menggunakan Metode Webqual 4.0
}

\author{
Evaluation of Service Quality for Alumni Website \\ Using Webqual 4.0 Method
}

\author{
Anisa Yulandari*1, Wing Wahyu Winarno ${ }^{2}$, Asro Nasiri ${ }^{3}$ \\ ${ }^{1,2}$ Magister Teknik Informatika, Universitas Amikom Yogyakarta, \\ ${ }^{3}$ Fakultas Ilmu Komputer, Universitas Amikom Yogyakarta \\ E-mail: *13anisa.y@students.amikom.ac.id, ${ }^{2}$ wing@Amikom.ac.id, ${ }^{3}$ asro@Amikom.ac.id
}

\begin{abstract}
Abstrak
Website Portal Alumni Amikom Yogyakarta yang dapat diakses pada alamat domain alumni.amikom.ac.id merupakan bagian dari Universitas Amikom Yogyakarta yang berfungsi sebagai sarana berbagi informasi sekaligus bertindak sebagai penghubung antara perusahaan pencari tenaga kerja dan para pencari kerja khususnya alumni Universitas Amikom Yogyakarta. Selama ini website alumni sudah berjalan belum dilakukan evaluasi terhadap kualitas layanan website yang didasarkan pada persepsi pengguna akhir sebagai umpan balik kepada pengelola website sehingga pengelola dapat mengetahui sejauh mana kepuasan pengguna dan kualitas layanan yang sudah diberikan. Tujuan dari penelitian ini yaitu untuk mengetahui kualitas layanan website alumni menggunakan tiga dimensi yang ada pada metode Webqual 4.0. Tiga dimensi itu sendiri terdiri dari Kegunaan, Kualitas Informasi, dan Kualitas Interaksi Layanan. Pendistribusian kuisioner dilakukan terhadap 200 sampel responden. Kesimpulan dari penelitian ini adalah adanya pengaruh ketiga dimensi Webqual 4.0 terhadap kepuasan pengguna. Dimensi yang paling berpengaruh yaitu Kualitas Informasi dan Kualitas Interaksi Layanan. Hal ini berarti peningkatan dapat dilakukan pada indicator yang memiliki nilai rata-rata terendah. Peningkatan pada dimensi Kualitas Informasi dapat dilakukan perbaruan secara berkala sehingga informasi yang disajikan menjadi lebih relevan. Sedangkan untuk dimensi Kualitas Interaksi Layanan dapat dilakukan dengan meningkatkan pelayanan terhadap keluhan seputar website alumni.
\end{abstract}

Kata Kunci - Kualitas Layanan, Website Alumni, Webqual 4.0

Abstract

The Alumni Amikom Yogyakarta Website which can be accessed at the domain address alumni.amikom.ac.id is part of the Amikom University of Yogyakarta which serves as a means of sharing information while acting as a liaison between the company and job seekers, especially alumni of Yogyakarta Amikom University. So far, the alumni website has been running, yet an evaluation of the quality of website services has been carried out based on the perception of the end user as feedback to the website manager so that the manager can find out how far the user satisfaction is and the quality of the service provided. The purpose of this study is to determine the quality of the alumni website service using three dimensions that exist in the method of Webqual 4.0, there are Usability, Information Quality, and Service Interaction Quality. The conclusion of this study is the influence of the three dimensions of Webqual 4.0 on user satisfaction. The most influential dimensions are Information Quality and Service Interaction Quality. This means that an increase can be made on an indicator that has the lowest average value

Keywords - Quality of Service, Alumni Website, Webqual 4.0 


\section{PENDAHULUAN}

Kualitas perguruan tinggi dapat dilihat dari beberapa faktor, salah satunya yaitu lulusannya atau alumni. Alumni menjadi hal penting dalam suatu perguruan tinggi karena berkaitan langsung dengan dunia kerja sehingga data dan informasi mengenai alumni menjadi salah satu penilaian dalam penentuan akreditasi program studi [1].

Keberadaan alumni penting bagi perguruan tinggi dalam tiga hal. Pertama, adalah nilai jual kampus yang terdongkrak oleh prestasi alumninya. Nilai jual itu setidaknya tercermin dalam seleksi penerimaan mahasiswa baru. Perguruan tinggi yang memiliki alumni dan sudah terbukti kiprahnya lebih diminati oleh calon mahasiswa. Selain itu, perguruan tingggi juga lebih berkesempatan untuk mendapatkan proyek kerjasama, baik dari industri swasta maupun pemerintahan. Permintaan riset, keterlibatan sebagai konsultan, dan pengucuran donasi akan mengalir deras. Alumni menjadi jaminan reputasi kampus dan kehandalan sumber daya manusianya. Kedua, alumni berperan dalam pengembangan perguruan tinggi. Umpan balik alumni sudah malang-melintang dalam dunia profesional sangat penting dalam peningkatan kualitas perguruan tinggi. Selain lebih mudah karena faktor kedekatan, saran dan masukan dari alumni sendiri tentunya lebih murah daripada harus menggunakan metode survei. Ketiga, kemudahan mendapatkan pekerjaan bagi lulusan baru. Tidak jarang, faktor relasi sealmamater cukup mempengaruhi preferensi pemberi kerja. keberadaan alumni yang sudah menduduki top managament atau middle posititon management merupakan berkah tersendiri bagi adik angkatannya [2].

Selain itu, alumni juga penting bagi perkembangan industri. Adanya hubungan timbal balik antara akademia dan industri, dimana industri memberikan arahan penelitian untuk akademisi, sehingga hasil penelitian mereka dapat membantu industri. Setiap riset didefinisikan sebagai tantangan industri yang relevan dalam membantu produktifitas industri sehingga akademisi diharapkan dapat memecahkan permasalahan industri [3].

Pembuatan website alumni pada lembaga pendidikan saat ini mulai dikembangkan karena kegunaanya dinilai penting. Web alumni bertujuan untuk mempermudah perusahaan maupun institusi dalam melakukan pekerjaan mereka yang dapat memonitoring kegiatan alumni [4]. Dengan adanya website alumni, perguruan tinggi dapat memonitoring para alumninya yang belum maupun sudah terserap dalam duni kerja. Sedangkan untuk perusahaan mendapatkan informasi mengenai alumni perguruan tinggi yang dapat direkrut untuk mengisi posisi yang dibuthkan dalam perusahaan.

Universitas Amikom Yogyakarta merupakan perguruan tinggi swasta di Yogyakarta sebagai penghasil alumni menyediakan website alumni yang dapat diakses pada domain http://alumni.Amikom.ac.id. Bertujuan untuk menjembatani perusahaan selaku pencari tenaga kerja dan pencari kerja khususnya alumni Universitas Amikom Yogyakarta. Namun belum ada evaluasi yang dilakukan terhadap website tersebut dari sisi penggunanya. Oleh karena itu penelitian ini melakukan evaluasi terhadap website alumni Universitas Amikom Yogyakarta dari sisi pengguna internal yaitu alumni Universitas Amikom Yogyakarta, untuk mengetahui kualitas layanan serta kepuasan pengguna website alumni Universitas Amikom Yogyakarta.

Menurut Belash dkk, terdapat beberapa faktor yang dapat memonitoring tingkat kepuasan tersebut. Diantaranya lulusan atau alumni yang baru saja lulus kemudian melanjutkan pendidikan ke jenjang selanjutnya dan lulusan atau alumni yang telah bekerja setelah 2-3 tahun setelah lulus [5].

Soejono dkk, melakukan penelitian terhadap kualitas website UNRIYO yang diukur menggunakan metode System Usability Scale (SUS). Kelima variabel SUS yakni Learnability, Efficiency, Memorability, Errors, dan Satisfaction memberikan pengaruh terhadap kualitas website UNRIYO. Hasil yang diperoleh dari penelitian ini yaitu tingkat kualitas website UNRIYO dinilai belum baik dari segi Usability sehingga dibutuhkan perbaikan. Kelemahan dari metode SUS yaitu hanya menilai dari sisi Usability atau kegunaannya saja namun belum dapat menilai kualitas layanan serta informasi yang terdapat dalam website tersebut. Perbedaan penelitian soejono dengan penelitian yang akan dilakukan yaitu penilaian kualitas website dilihat tidak 
hanya dari sisi Usability atau kegunaannya saja namun juga menilai kualitas informasi maupun kualitas interaksi daripada layanan website [6].

Budhi dkk, melakukan penelitian terhadap pelayanan di Century Gym untuk mengetahui indek kepuasan dari penggunanya. Costumer Satisfaction Index (CSI) merupakan metode yang digunakan dalam penelitian ini. Tujuan dari penelitian ini adalah untuk meningkatkan kinerja pelayanan, fasilitas dan penanganan keluhan pelanggan. Hasil yang diperoleh dari penelitian ini yaitu dari kelima atribut CSI diantaranya bukti fisik, keandalan, daya tanggap, jaminan dan empati, atribut bukti fisik merupakan atribut yang paling berpengaruh terhadap kepuasan pengguna. Kelemahan dari penelitian ini yaitu belum dapat menilai kualitas informasi yang terdapat dalam website tersebut. Penelitian yang akan dilakukan oleh peneliti dalam evaluasi terhadap kualitas layanan website alumni, menilai kualitas layanan website dari beberapa sisi yaitu kegunaan, kualitas informasi serta kualitas interaksi layanan yang diberikan oleh pengelola website kepada pengguna website (end user) [7].

Eli juga melakukan penelitian pada website E-commerce khusus toko online fashion yang menilai kualitas website tersebut berdasarkan persepsi pengguna internet yang pernah bertransaksi dan pada pengguna yang belum pernah bertransaksi namun memiliki keinginan untuk bertransaksi dikemudian hari pada website tersebut. Pada penelitianya penulis menggunakan dimensi yang terdapat pada Trust Building Model (TBM) terkait kualitas website yang berhubungan dengan kepercayaan penggunanya. Hasil yang diperoleh dari penelitian ini yaitu kepercayaan pengguna sangat dipengaruhi oleh kualitas website serta keamanan yang tersaji melalui website, sedangkan reputasi vendor melalui website tidak signifikan mempengaruhi konsumen untuk bisa lebih percaya pada suatu vendor toko online fashion. Kelemahan dari penelitian ini belum mengukur kualitas website berdasarkan kualitas layanan interaksi yang diberikan oleh pengelola website e-commerce kepada penggunanya. Perbedaan penelitian eli dengan penelitian yang akan dilakukan yaitu penilaian kualitas website dilihat dari sisi kegunaan, kualitas informasi maupun kualitas interaksi daripada layanan website [8].

Penelitian selanjutnya dilakukan oleh Fitiansyah dkk, pada Universitas Universal bertujuan untuk menilai kualitas layanan website kampus dari sisi kepuasan pengguna. Metode yang digunakan untuk mengukur kualitas website yaitu End User Computing Satisfaction (EUCS) yang mengandung variabel Content, Accuracy, Format, Ease of Use, dan Timeliness. Hasil yang diperoleh dari penelitian ini yaitu kualitas website dinilai sudah cukup baik dan pengguna merasa puas dengan layanan yang diberikan oleh website. Kelemahan dari metode EUCS yaitu belum dapat menilai kualitas dari interaksi layanan yang diberikan oleh website kepada penggunanya. Penelitian yang akan dilakukan, menilai kualitas layanan website alumni dari segi kegunaan, kualitas informasi dan kualitas interaksi layanan yang diberikan oleh pengelola kepada penguna website alumni [9].

Sujono dkk, pernah melakukan penelitian terhadap kualitas layanan website E-Learning dari sisi kepuasan pengguna yang diukur menggunakan variabel dalam metode Webqual. Ketiga variabel Webqual yakni Usabillity, Information Quality, dan Interaction Service Quality, diperoleh hasil variabel Usability yang paling berpengaruh terhadap kepuasan pengguna. Perbedaan penelitian sujono dengan penelitian yang akan dilakukan yaitu, peneliti menerapkan metode Webqual untuk menilai kualitas layanan website alumni yang ada di Universitas AMikom Yogyakarta [10].

Rahmad dkk, meneliti metode DeLone dan McLean untuk mengukur kesuksesan media pemasaran online (E-commerce) terhadap kepuasan pengguna (User satisfaction), dan niat untuk menggunakan E-Commerce tersebut kembali (Intention to use). Hasil yang diperoleh menunjukkan variabel information quality, system quality, dan user quality berpengaruh langsung terhadap user satisfaction, dan user satisfaction berpengaruh langsung terhadap variabel intention to use, sedangkan variabel intention to use berpengaruh secara tidak langsung terhadap variabel manfaat yang diperoleh pengguna (net benefit). Penelitian yang akan dilakukan oleh peneliti dalam evaluasi terhadap kualitas layanan website alumni, menilai kualitas layanan website dari beberapa sisi yaitu kegunaan, kualitas informasi serta kualitas interaksi layanan yang diberikan oleh pengelola website kepada pengguna website (end user) [11]. 
Furkonudin dkk, dalam penelitiannya menggunakan objek penelitian website Ecommerce Blibli.com dengan fokus meneliti pengaruh kualitas layanan website terhadap kepuasan pengguna dan niat menggunakan kembali website yang diukur menggunakan metode Webqual. Hasil penelitian menunjukkan semua dimensi webqual berpengaruh signifikan terhadap keputusan pembelian online. Dimensi kualitas interaksi (Interaction Quality) merupakan dimensi yang paling dominan berpengaruh terhadap keputusan pembelian online. Perbedaan dengan penelitian yang akan dilakukan oleh peneliti yaitu peneliti menerapkan metode Webqual untuk mengukur kualitas layanan website alumni Universitas Amikom Yogyakarta dengan alumni sebagai respondennya [12].

Berdasarkan permasalahan metode yang telah dipaparkan diatas, peneliti mengusulkan melakukan penelitian terhadap website Alumni Universitas Amikom Yogyakarta dengan menggunakan metode Webqual. Metode Webqual dapat mengukur kualitas website dari segi Usability, Information Quality, dan Service Interaction Quality. Ketiga dimensi tersebut dapat menjawab permasalahan kebutuhan pengguna terhadap kualitas website yang dikelola oleh instansi. Webqual merupakan salah satu metode pengukuran yang biasanya digunakan dalam mengukur kualitas website. Pertama kali dikembangkan oleh Stuart Barnes dan Richard Vidgen [13].

Webqual mengacu pada “Quality Function Deployment” (QFD) yaitu suatu proses yang berdasar pada persepsi pengguna dalam mengembangkan dan mengimplementasikan suatu produk atau jasa. Dari konsep QFD tersebut, Webqual dibentuk berdasar pada persepsi pengguna akhir (End User) terhadap suatu website. Webqual mengalami beberapa iterasi dalam penyusunan dimensi dan butir-butir pertanyaannya. Versi terbaru Webqual 4.0 menggunakan 3 dimensi pengukuran dan 22 butir pertanyaan. Ketiga kategori tersebut adalah Kegunaan (Usability), Kualitas Informasi (Information Quality), dan Kualitas Interaksi Layanan (Interaction Service Quality). Dimensi kegunaan merupakan kajian mengenai hubungan interaksi antara manusia dan komputer serta kajian mengenai kegunaan website, diantaranya mengenai kemudahan navigasi, kecocokan desain, dan gambaran disajikan kepada pengguna. Kualitas informasi disusun berdasarkan kajian sistem informasi secara umum. Dimensi ini berkaitan dengan konten daripada website tersebut, diantaranya akurasi, format dan relevansi informasi yang disajikan kepada pengguna. Dimensi kualitas interaksi layanan berkaitan dengan interaksi layanan yang dirasakan pengguna ketika terlibat dalam secara mendalam dengan website [14].

Penelitian ini diharapkan dapat memberikan kontribusi kepada pengelola website alumni Universitas Amikom Yogyakarta dalam mengembangkan website alumni Amikom. Hasil dari penelitian ini akan menjadi dasar untuk memberikan rekomendasi perbaikan layanan website alumni Universitas Amikom Yogyakarta berdasarkan dimensi-dimensi yang diteliti pada penelitian ini.

\section{METODE PENELITIAN}

Penelitian ini menggunakan empat variabel yang mengacu metode Webqual 4.0. Variabel yang digunakan antara lain kegunaan (usability quality), kualitas informasi (information quality), kualitas interaksi layanan (service interaction quality) dan kualitas layanan website (website services quality). Adapun definisi operasional variabel yang digunakan dalam penelitian ini adalah sebagai berikut [15]:

a. Usability quality merupakan kualitas yang berkaitan dengan navigasi dan gambaran yang diberikan kepada pengguna.

b. Information quality merupakan kualitas yang berkaitan dengan konten website, kesesuaian informasi yang disajikan kepada pengguna seperti akurasi, format, dan relevansi.

c. Service interaction quality merupakan kualitas yang berkaitan dengan pengalaman berinteraksi dan pelayanan yang dirasakan oleh pengguna.

d. Website services quality merupakan kualitas layanan website yang disediakan oleh website sistem [16]. 
Citec Journal, Vol. 5, No. 2, Februari 2018 - April 2018

Adapun hipotesis yang dikemukakan pada peneltian ini dapat dilihat pada Gambar 1.

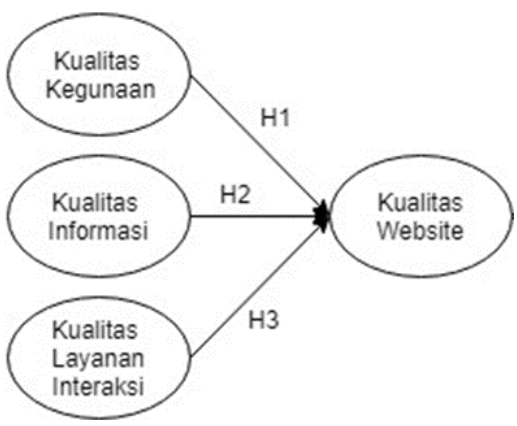

Gambar 1. Hipotesis Penelitian

H1 : Kualitas kegunaan (Usability quality) berpengaruh positif terhadap kualitas layanan website (Website services quality).

H2 : Kualitas informasi (Information quality) berpengaruh positif terhadap kualitas layanan website (Website services quality).

H3 : Kualitas layanan interaksi (Interaction services quality) berpengaruh positif terhadap kualitas layanan website (Website services quality).

Populasi dalam penelitian ini adalah alumni universitas Amikom yang memiliki pengalaman mengakses website alumni Amikom lebih dari sekali dan telah mengakses hampir semua menu yang terdapat pada website alumni tersebut. Pengambilan sampel masuk dalam nonprobability sampling sehingga teknik yang dapat digunakan yaitu quota sampling. Pemilihan matrik estimasi dalam penelitian ini menggunakan maximum likehood estimation yang menyarankan menggunakan 100-200 sampel.

Analisa data pada penelitian ini menggunakan SEM (Structural Equation Modeling) atau Pemodelan Persamaan Struktural yaitu analisis yang menggabungkan pendekatan analisa faktor (factor analysis), model structural (structural model) dan analisis jalur (path analysis) [17]. Analisa SEM akan dilakukan menggunakan software AMOS 23.

Adapun alur dari penelitian ini dapat dilihat pada Gambar 2.

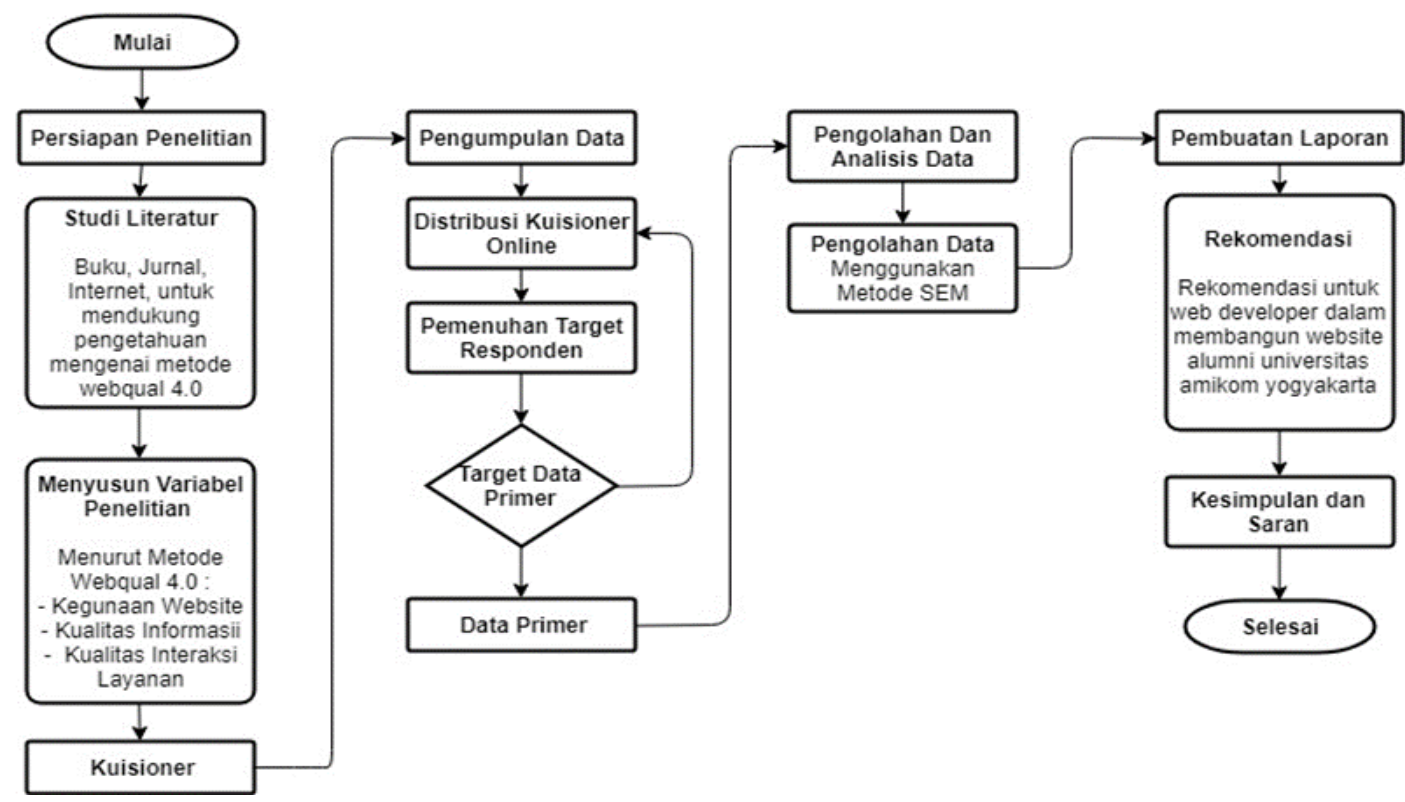

Gambar 2. Alur Penelitian 


\section{HASIL DAN PEMBAHASAN}

Analisa data pada penelitian ini menggunakan analisa SEM dengan bantuan software AMOS 23. Jumlah kuisioner yang disebar sebanyak 200 dengan harapan diperoleh data valid sebanyak 143 data. Dengan sebaran data responden laki-laki berjumlah 77 atau 53,85 persen dan perempuan sebanyak 66 atau 46,15 persen.

Untuk memudahkan penyebutan variabel, maka peneliti membuat singkatan dari setiap variabel yang selanjutnya akan disebut dalam penelitian ini, diantaranya Usability Quality (UQ), Information Quality (IQ), Interaction Services Quality (ISQ), dan Website Service Quality (WSQ). Indikator dimensi webqual dapat dilihat pada Tabel 1.

Tabel 1. Indikator Dimensi Webqual

\begin{tabular}{|l|l|c|}
\hline \multicolumn{1}{|c|}{ Dimensi } & \multicolumn{1}{|c|}{ Indikator } & Singkatan \\
\hline Usability & Interaksi jelas dan dapat dimengerti & UQ1 \\
\hline & Mudah melakukan navigasi & UQ2 \\
\hline & Tampilan menarik & UQ3 \\
\hline & Desain sesuai & UQ4 \\
\hline & Daya saing & UQ5 \\
\hline & Mudah dipelajari dan dioperasikan & UQ6 \\
\hline & Mudah digunakan & UQ7 \\
\hline & Pengalaman positif & UQ8 \\
\hline Information & Informasi akurat & IQ1 \\
\hline & Informasi dapat dipercaya & IQ2 \\
\hline & Informasi actual & IQ3 \\
\hline & Informasi relevan & IQ4 \\
\hline & Informasi mudah dimengerti & IQ5 \\
\hline & Informasi dengan tingkat detail yang tepat & IQ6 \\
\hline & Informasi dalam format yang sesuai & IQ7 \\
\hline Interaction Services & Reputasi baik & ISQ1 \\
\hline & Keamanan informasi pribadi & ISQ2 \\
\hline & Pelaksanaan layanan sesuai janji & ISQ3 \\
\hline & Kemudahan berkomunikasi dengan perusahaan & ISQ4 \\
\hline Website Service Quality & Output dari proses layanan & WSQ1 \\
\hline & Informasi yang disajika & WSQ2 \\
\hline & Proses pelayanan yang diberikan & WSQ3 \\
\hline
\end{tabular}

Analisa data diawali dengan pengujian model pengukuran, dengan cara menguji validitas dan reliabilitas. Untuk menilai validitas, digunakan acuan nilai average variance extracted (AVE) $>0.5$ seperti ditunjukkan pada Tabel 2 .

Tabel 2. Nilai Average Variance Exptracted (AVE)

\begin{tabular}{|c|c|}
\hline Variabel Laten & AVE \\
\hline Kegunaan & 0.501 \\
\hline Kualitas Informasi & 0.530 \\
\hline Kualitas Interaksi Layanan & 0.534 \\
\hline Kualitas Website & 0.734 \\
\hline
\end{tabular}

Tabel 2 menunjukkan nilai AVE untuk setiap variabel yang digunakan memenuhi syarat $>0.5$ sehingga indicator-indikator yang mewakili variabel-variabel tersebut dinyatakan valid. Sedangkan untuk mengukur reliabilitas dilakukan dengan dua cara yaitu composite reliability > 0.7 dan cronbach's alpha $>0.6$. 
Citec Journal, Vol. 5, No. 2, Februari 2018 - April 2018

Tabel 3. Nilai Composite Reliability

\begin{tabular}{|l|c|c|}
\hline \multicolumn{1}{|c|}{ Variabel Laten } & Composite Reliability & Cronbach's Alpha \\
\hline Kegunaan & 0.857 & 0.802 \\
\hline Kualitas Informasi & 0.870 & 0.822 \\
\hline Kualitas Interaksi Layanan & 0.872 & 0.832 \\
\hline Kualitas Website & 0.916 & 0.881 \\
\hline
\end{tabular}

Tabel 3 menunjukkan nilai Composite Reliabilty dan Cronbach’s Alpha untuk setiap variabel yang digunakan memenuhi syarat $>0.7$ dan $>0.6$ sehingga variabel-variabel digunakan dinyatakan reliabel.

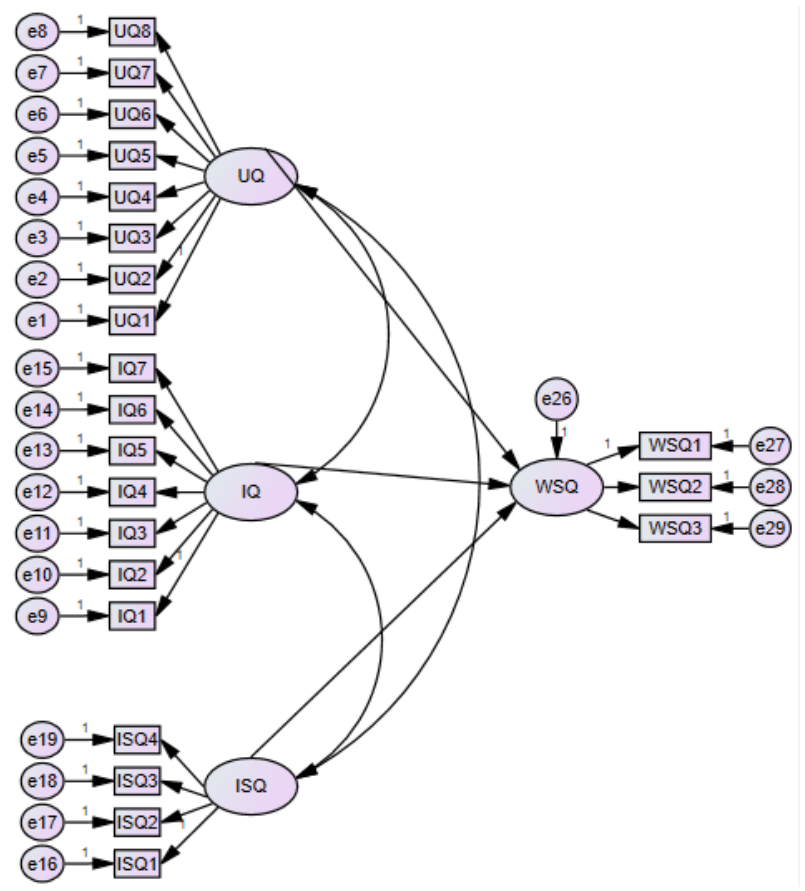

Gambar 3. Model Penelitian pada Amoss 23

Model awal pada penelitian ini dapat dilihat pada Gambar 3. Terdapat beberapa langkah perhitungan untuk memperoleh model penelitian yang fit. Dalam penenlitian ini hasil pengujian terhadap kriteria goodness of fit yakni CMIN/DF $=0,834$ yang berarti $\leq 2.00$ sehingga model dikatakan fit/baik.

Tabel 4. Kesesuaian Goodness of Fit

\begin{tabular}{|c|l|c|c|c|}
\hline No & Goodness of Fit Index & Kriteria & Hasil & Keterangan \\
\hline 1 & Chi-Square & $<77,93$ & 49,197 & Fit \\
\hline 2 & Probability & $\geq 0,05$ & 0,815 & Fit \\
\hline 3 & RMSEA & $\leq 0,08$ & 0,000 & Fit \\
\hline 4 & GFI & $\geq 0,90$ & 0,966 & Fit \\
\hline 5 & AGFI & $\geq 0,90$ & 0,948 & Fit \\
\hline 6 & CMIN/DF & $\leq 2,00$ & 0,834 & Fit \\
\hline 7 & TLI & $\geq 0,95$ & 1,011 & Fit \\
\hline 8 & CFI & $\geq 0,95$ & 1,000 & Fit \\
\hline
\end{tabular}

Berdasarkan hasil pengujian pada Tabel 4, diperoleh hasil kriteria yang fit/baik. Dari hasil tersebut maka secara keseluruhan dapat dikatakan bahwa model penelitian memiliki tingkat goodness of fit yang baik. 


\subsection{Uji Hipotesis}

Pengujian hipotesis dilakukan menggunakan analisis SEM, dengan cara menganalisis nilai regresi yang ada pada tabel Regression Weight.

Tabel 5. Hasil Uji Hipotesis

\begin{tabular}{|l|l|l|l|l|l|l|l|l|}
\hline \multicolumn{3}{|c|}{ Hipotesis } & Estimate & \multicolumn{1}{|c|}{ S.E } & C.R & \multicolumn{1}{c|}{ P } & \multicolumn{1}{|c|}{ Keterangan } \\
\hline H1 & WSQ & $<----$ & UQ & .093 & .076 & 1,225 & .221 & Tidak Signifikan \\
\hline H2 & WSQ & $<----$ & IQ & .299 & .069 & 4,336 & $* * *$ & Signifikan \\
\hline H3 & WSQ & $<----$ & ISQ & .253 & .080 & 3,156 & .002 & Signifikan \\
\hline
\end{tabular}

Pada Tabel 5 pengujian hipotesis dilakukan dengan kriteria uji Probabilitas (P) $<0.05$ dan Critical Ratio (C.R) > 1,96. Apabila hasil uji menunjukkan nilai yang memenuhi syarat tersebut, maka hipotesis penelitian yang diajukan dapat diterima. Berdasarkan Tabel 5, dimensi Usability Quality (UQ) tidak memiliki hubungan yang signifikan terhadap dimensi Website Service Quality (WSQ) karena memiliki nilai C.R dan P yang tidak memenuhi syarat sehingga hipotesis ditolak.

\subsection{Rekomendasi}

Hasil pengujian hipotesis menjadi dasar peneliti untuk memberikan rekomendasi kepada pengelola website alumni Universitas Amikom Yogyakarta dalam mengembangkan website sehingga dapat memberikan layanan yang lebih baik.

a. Berdasarkan pengujian hipotesis kualitas informasi memiliki pengaruh yang signifikan terhadap kualitas layanan website. Oleh karena itu, pengelola dapat meningkatkan kualitas daripada informasi yang ada pada website alumni Universitas Amikom Yogyakarta. Hal tersebut dapat dilakukan dengan cara memperbaharui informasi berita seputar pekerjaan, workshop, dan kegiatan alumni lainnya secara berkala.

b. Kualitas interaksi layanan memiliki pengaruh yang signifikan terhadap kualitas website. Oleh karena itu pengelola dapat meningkatkan kualitas pada dimensi ini. Hal tersebut dapat dilakukan dengan meningkatkan pelayanan terhadap penanganan keluhan seputar website alumni Universitas Amikom Yogyakarta.

\section{KESIMPULAN}

Website alumni Universitas Amikom Yogyakarta merupakan dimensi yang paling berpengaruh terhadap kualitas layanan website. Diikuti oleh dimensi kualitas interaksi layanan yang juga memberikan pengaruh yang signifikan terhadap kualitas layanan website Universitas Amikom Yogyakarta. Hal ini berarti perlu adanya perhatian terhadap informasi serta interaksi layanan dalam meingkatkan kualitas layanan website alumni Universitas Amikom Yogyakarta. Terdapat temuan dalam penelitian ini yaitu kualitas kegunaan pada metode Webqual 4.0 tidak memiliki pengaruh yang signifikan terhadap kualitas layanan website alumni.

\section{SARAN}

Diharapakan pada penelitian selanjutnya dapat diperoleh temuan baru terkait pengukuran kualitas layanan website alumni sehingga dapat membantu pengelola website dalam meningkatkan kualitas websitenya. Diharapkan juga pengembangan terhadap metode Webqual 4.0 sehingga kedepannya metode ini tidak hanya dapat digunakan untuk mengukur kualitas layanan website saja namun juga dapat mengukur tingkat kesuksesan penerapan website. 


\section{DAFTAR PUSTAKA}

[1] Ahmad, A, L., 2017, Aplikasi Tracer Study Berbasis Website Responsive Pada Fakultas Universitas Jendral Soedirman Purwokerto, INTI, Vol. 13, No. 2, Hal 125- 132.

[2] Muhibbin, 2012, Peran Media Dalam Hubungan Perguruan Tinggi dan Alumninya. https://www.kompasiana.com/bayumw/55619fe670977394789bbf1b/peran-media-dalamhubungan-perguruan-tinggi-dan-alumninya.

[3] K Hansen, 2016, Creating a Successful Partnership Between Industry, Academia and Goverment, IEEE Design \& Test, September - Oktober 2016, Hal. 84-91

[4] C Sinaga, 2018, Web Monitoring Alumni Politeknik Telkom Bandung. [Online]. http://www.repository.politekniktelkom.ac.id, diakses tanggal 24 September 2018.

[5] Belash, O.,E., 2015, Research on University Education Quality Assurance: Methodology and Result of Stakeholders Satisfaction Monitoring, Procedia-Social and Behavioral Sciences, Bulgaria, 15-18 June.

[6] Soejono, A.,W., 2018, Evaluasi Usability Website UNRIYO Menggunakan System Usability Scale (Studi Kasus: Website UNRIYO), Jurnal Teknologi Informasi, Vol. 13, No. 1, Hal 2937.

[7] Sumiari, N .K., Budhi, I. G. kt. T. P., 2017, Pengukuran Customer Satisfaction Index Terhadap Pelayanan di Century Gym, Jurnal Ilmiah SISFOTENIKA, Vol. 7, No. 1, Hal 2537.

[8] Winarno, W. W., Sudarmawan, Astuti, E. P., 2014, Pengaruh E-Commerce Toko Online Fashion Terhadap Kepercayaan Konsumen, Citec Journal, Vol 1, No 2, Hal. 65-77.

[9] Firtiansyah, A.,I., 2018, Pengukuran Kepuasan Pengguna Situs Web Dengan Metode End User Computing Satisfaction (EUCS), Jurnal Sistem Informasi, Vol. 2 No. 1, Hal 1-8.

[10] Sujono, 2017, E-Learning Quality Analysis of Use of Web Conference in The Improvement of Students with Learning Method Webqual, International Journal of Science and Technology, Vol. 6 No.1, Hal 8-14.

[11] Rahmad, 2017, Analisis Dampak Kepercayaan Pada Pengguna Media Pemasaran Online (Ecommerce) yang Diadopsi oleh UMKM: Perspektif DeLone McLean, Jurnal Manajemen Teknologi. Vol. 16 No.3, Hal 310 - 337.

[12] Suryadi, E., Darmanto, Furkonidin, 2016, Evaluasi Kualitas Layanan Website E-commerce Blibli.com Menggunakan Metode Webqual 4.0 Terhadap Keputusan Pembelian Online, Seminar Nasional Teknologi Informasi dan Multimedia. Yogyakarta, 6-7 Februari.

[13] Anwar, M.,F., S. Hermawati B.S. Santosa, 2015 , Analisa Kualitas Website Menggunakan Metode Webqual dan Importance Performance Analysis (IPA) Pada situs Kaskus, National Conference on Information Technology and Technical Engineering (CITEE). Yogyakarta, 15 September.

[14] Barnes, S., Vidgen, R., 2000, WebQual: An Exploration of Web-Site Quality, Proceedings of the 8th European Conference on Information Systems, Trends in Information and Communication Systems for the 21st Century, ECIS, Viena, 3-5 Juli 2000.

[15] Tarigan, J., 2008, User Satisfaction Using Webqual Instrument: A Research on Stock Exchange of Thailand (SET), Jurnal Akuntansi dan Keuangan, Vol. 10, No. 1, Hal. 34-47.

[16] L. W., \& Jiao, A. Y Zhong, 2008 , The Impact of Website and Offline Quality on Relationship Quality: An Empirical Study on E-retailing., Proceedings of 4th International Conference on Wireless Communications, Networking and Mobile Computing Conference (WICOM), China, 12-17 October.

[17] Sugiyono, 2012, Statistika Untuk Penelitian. CV. Alfabeta, Bandung. 